\title{
Basidiobolomycosis: An Emerging Fungal Infection of the Gastrointestinal Tract in Adults
}

\author{
${ }^{1}$ Adil Hassan Alshehri, ${ }^{2}$ Abdullah Alshehri, ${ }^{3}$ Mohammed Abdullrahman Bawahab, \\ ${ }^{1,2}$ Suliman Al-Humayed, ${ }^{2}$ Khalid Nabrawi, ${ }^{3}$ Fahad Saeed Alamri and ${ }^{2}$ Abdulilah Hassan Alshehri \\ ${ }^{1}$ Department of Internal Medicine, Faculty of Medicine, King Khalid University, Abha, Saudi Arabia \\ ${ }^{2}$ Department of Internal Medicine, Gastro-Unite, Aseer Central Hospital, Ministry of Health, Abha, Saudi Arabia \\ ${ }^{3}$ Department of General Surgery, Faculty of Medicine, King Khalid University, Abha, Saudi Arabia
}

Received 2013-03-11, Revised 2013-03-17; Accepted 2013-03-18

\begin{abstract}
Basidiobolomycosis is an unusual fungal infection known for dermatological manifestations that affect immunocompetent young adult and rarely involves the gastrointestinal tract, during the past decade many cases have been reported in Saudi Arabia with diagnosis of gastrointestinal basidiobolomycosis, most of the reported cases were in children and majority came from southern region of Saudi Arabia and all were misdiagnosed initially as either IBD or granulomatous diseases or malignancy. GIB poses diagnostic difficulties due to nonspecific presentations and rarity and has been scarcely reported in medical literatures. GIB might be a life threatening infection. So, a high index of suspicion is warranted in any child or young adult with differential diagnosis of IBD, granulomatous disease and malignancy affecting GI tract especially those patients whom are residents in or came from southern region of Saudi Arabia. In this series which is the largest reported series in adult patient with GIB in this country, we describe 4 cases of GI basidiobolomycosis from southern Region of Saudi Arabia.
\end{abstract}

Keywords: Basidiobolomycosis, Gastrointestinal, Basidiobolus, Granulomatous

\section{INTRODUCTION}

Basidiobolus species are filamentous fungi that belong to the family basidiobolaceae, of the order entomophthorales, they are occasionally present as a commensal in the gastrointestinal tract of amphibians, reptiles, fish and mammals such as toads, turtles, chameleons, horses, dogs and bats and it is commonly found in soil and decaying vegetable matter (Greer and Friedman, 1966; Zahari et al., 1990; Gugnani, 1983). In the past, clinical isolates of Basidiobolus were classified as B. ranarum, B. merisstosporus and B.haptosporus. However, recent taxonomic studies based on antigenic analysis, isoenzyme banding and restriction enzyme analysis indicate that all human pathogens belong to $B$. ranarum (Khan et al., 2001; Sujatha et al., 2003). B. ranarum was first described by Eidam in 1886 as an isolate from frogs and it was later cultured from intestinal contents (Sutherland-Campbell, 1929; Thaxter, 1888 ) and the excreta of frogs. Basidiobolomycosis in general was recognized as the first human case of subcutaneous mycosis in Indonesia (Joe et al., 1956). Thereafter, start to be increasingly identified as one of the chronic subcutaneous fungal infections with most of the cases have been reported from tropical and subtropical regions (Sugar, 2010) and thought to be due to traumatic inoculation (Cameroon, 1990). GI basidiobolomycosis has been scarcely reported in the literatures and the total reported cases since 1964 till end 2012 were 44 cases worldwide. Recently, its etiologic role in gastrointestinal infections has been increasingly recognized in Saudi Arabia (Jarie et al., 2003; ElShabrawi et al., 2011; Hussein et al., 2007). To our knowledge 11 cases of GI basidiobolomycosis have been reported in Saudi Arabia: 10 cases in children and 1 case in young adult most of them came from southern region.

Corresponding Author: Adil Hassan Alshehri, Department of Medicine, Faculty of Medicine, King Khalid University, Abha, P.O. Box 9006, Zip Code 61413, Saudi Arabia Tel: +966555761694 


\section{MATERIALS AND METHODS}

\subsection{Case Definition}

Each case was diagnosed based on typical histopathology findings (granulomatous inflammation with tissue eosinophilia and presence of broad fungal hyphae on Gomorimethenamine silver stain) and isolation of $B$. ranarumfrom colonoscopic biopsies or surgical specimens.

\subsection{Medical Record Review}

Health records of four adult patient ( $\geq 18$ years of age) with GIB were retrospectively reviewed. All of those patient were diagnosed at Aseer Central Hospital (A tertiary health care center in southern region of Saudi Arabia). Data collected included symptoms, signs, laboratory, radiologic studies, endoscopic features, surgical interventions, treatment and outcome.

\section{RESULTS}

Table 1 provides detailed clinical, laboratory, radiological, endoscopic features, surgical interventions and outcome of all patients included. In this series, all the cases were misdiagnosed initially: two as colon cancer; one as IBD; one as appendicitis. The colon was involved in all of them with initial presenting symptoms of abdominal pain and fever in all patients; abdominal mass in three patients; marked weight loss in three patients and diarrhea in two patients. All patients had high ESR and hypochromic microcytic anemia; three had leukocytosis among them two had eosinophilia. Colonoscopy wise all had severe deep bleeding ulcers and three of them had fungating masses. Radiologically, one patient presented with huge dilatation of large bowel without real obstruction which was not reported before and three patients presented with masses. One patient responded well to treatment; three patients died from advanced disease and hospital acquired infections. One of them complicated by fistulae formation mimicking Crohn's disease which also, up to our knowledge, not reported before. Three patient underwent surgical interventions and all received Itraconazol.

\subsection{Case 1}

A previously healthy 24 years old Saudi male presented with history of abdominal pain, diarrhea, intermittent fever and marked weight loss; $15 \mathrm{~kg}$ for four months, on physical examination he was chronically ill looking with normal vital signs and BMI of 21 , he had tenderness in right iliac fossa with palpable tender hard and mobile mass. His laboratory testing showed WBC $14.4 \times 10^{3} \mathrm{uL}^{-1}$ with $22 \%$ eosinophilia, $\mathrm{Hg} 7.1 \mathrm{gm} \mathrm{dL}^{-1}$, HCT 22.3\%, MCV 55.3fL, MCH 17.3pg and platelet $1008 \times 10^{3} \mathrm{uL}^{-1}$, other laboratory testing include renal and liver function tests were normal apart from reduced albumin level $2.9 \mathrm{~g} \mathrm{dL}^{-1}$ and ESR $130 \mathrm{~mm} \mathrm{~h}^{-1}$. CT of the abdomen with contrast showed large bowel wall thickening seen in the cecum, ascending and transverse colon with involvement of the terminal ileum and multiple mesenteric lymph node enlargement Fig.1a-c, Colonoscopy showed deformed cecum with incompetent ileocecal valve with severe ulceration and nodularity of the distal part of terminal ileum and cecum with polypoidal mass at distal part of ascending colon Fig. 2a. Colonoscopic biopsies showed heavily infiltrated tissue by an acute and chronic inflammatory cells with nonspecific features to suggest either tuberculosis or crohn's disease, an open extended right hemicoloectomy was done Fig. 3a and $\mathbf{b}$ and the mass specimen examined histopathologiclly which showed features of granulomatous inflammation with tissue eosinophilia along with presence of fungal hyphae throughout the tissue that stained positively with GMS stain Fig. 4. Sabouraud dextrose agar for the surgical specimen grew B. ranarum. The patient did well postoperatively and was treated with Itraconazole for 1 year and he is asymptomatic.

\subsection{Case 2}

Previously healthy 21 years old Saudi female presented with abdominal pain mainly in the left lower quadrant, diarrhea alternate with constipation, intermittent fever and marked weight loss; 20 kilograms for eight months, on examination of this lady, she was ill looking patient with BMI of 11.49 and normal vital signs. She had generalized abdominal distension and tenderness in left iliac fossa without any palpable masses, her laboratory workup at presentation showed WBC $7 \times 10^{3} \mathrm{uL}^{-1}$ no eosinophilia, Hgb $8 \mathrm{~g} \mathrm{dL}^{-1}$, HCT $27.6 \%$, MCV $65.7 \mathrm{fL}$, MCH $20.5 \mathrm{pg}$, Plt $800 \times 10^{3} \mathrm{uL}^{-1}$, ESR $100 \mathrm{~mm} \mathrm{~h}^{-1}$, Creatinine $0.2 \mathrm{mg} \mathrm{dL}^{-1}$, $\mathrm{K} 3.1 \mathrm{mmol}$ $\mathrm{L}^{-1}$, Na $132 \mathrm{mmol} \mathrm{L}^{-1}$, Albumin $1.4 \mathrm{~g} \mathrm{dL}^{-1}$, Total Protein $6.6 \mathrm{~g} \mathrm{dL}^{-1}$ and normal liver enzymes. CT of the abdomen with contrast showed hugely dilated colon from the cecum till the rectum measuring $8 \mathrm{~cm}$ with circumfential wall thickening of the recto-sigmoid junction and mildly infiltrated fat planes Fig. 1d and e. 
Adil Hassan Alshehri et al. / American Journal of Infectious Diseases 9 (1): 1-6, 2013

Table 1. Clinical, laboratory, radiological and endoscopic features of four adult patients with GIB

\begin{tabular}{|c|c|c|c|c|c|c|c|c|c|}
\hline Patient & Age & Sex & $\begin{array}{l}\text { Clinical } \\
\text { presentation }\end{array}$ & $\begin{array}{l}\text { Abnormal } \\
\text { laboratory }\end{array}$ & $\begin{array}{l}\text { HIV } \\
\text { status }\end{array}$ & $\begin{array}{l}\text { Endoscopic } \\
\text { features }\end{array}$ & $\begin{array}{l}\text { Radiologic } \\
\text { finding }\end{array}$ & $\begin{array}{l}\text { Surgical } \\
\text { interventions }\end{array}$ & $\begin{array}{l}\text { Follow } \\
\text {-up }\end{array}$ \\
\hline 1 & $24 \mathrm{y}$. & Male & $\begin{array}{l}\text { Abdominal pain, } \\
\text { diarrhea, fever, } \\
\text { weight loss and } \\
\text { mass } / 4 \text { months. }\end{array}$ & $\begin{array}{l}\text { WBC } 14.422 \% \\
\text { eosinophilia - } \\
\text { Hypochromic } \\
\text { microcytic anemia- } \\
\text { Thrombocytosis- } \\
\text { Albumin 2.9- } \\
\text { ESR 130. }\end{array}$ & & $\begin{array}{l}\text { Deformed cecum, } \\
\text { incompetent ileocecal } \\
\text { valve severe } \\
\text { ulcerations and } \\
\text { nodularity in } \\
\text { terminal ileum } \\
\text { and polypoidal } \\
\text { mass in } \\
\text { ascending colon. }\end{array}$ & $\begin{array}{l}\text { Cecum, ascending } \\
\text { colon, Transverse } \\
\text { colon and terminal } \\
\text { ileum wall } \\
\text { thickening + } \\
\text { multiple L. } \\
\text { N. enlargement. }\end{array}$ & $\begin{array}{l}\text { Extended right } \\
\text { hemi-colectomy. }\end{array}$ & Asymptomatic. \\
\hline 2 & $21 \mathrm{y}$. & Female. & $\begin{array}{l}\text { Abdominal } \\
\text { pain, fever, } \\
\text { diarrhea, } \\
\text { and severe } \\
\text { weight loss/ } \\
8 \text { months. } \\
\text { Treated } \\
\text { initially } \\
\text { with steroid } \\
\text { as IBD. }\end{array}$ & $\begin{array}{l}\text { WBC } 7 \text { No } \\
\text { eosinophilia- } \\
\text { Hypochromic } \\
\text { microcytic } \\
\text { anemia- } \\
\text { Thrombo } \\
\text { cytosis- } \\
\text { Albumin 1.4- } \\
\text { ESR 100. }\end{array}$ & Neg. & $\begin{array}{l}\text { severe deep } \\
\text { ulceration with } \\
\text { polypoidal } \\
\text { lesions in } \\
\text { sigmoid } \\
\text { colon. }\end{array}$ & $\begin{array}{l}\text { Hugely dilated } \\
\text { colon with } \\
\text { wall thickening } \\
\text { of recto sigmoid } \\
\text { stranding of } \\
\text { mesenteric fat. }\end{array}$ & Non. & $\begin{array}{l}\text { Died from } \\
\text { severe } \\
\text { malnutrition } \\
\text { and repeated } \\
\text { hospital } \\
\text { acquired } \\
\text { infections. }\end{array}$ \\
\hline 3 & $72 \mathrm{y}$. & Male. & $\begin{array}{l}\text { Abdominal } \\
\text { masses and } \\
\text { fever/ } \\
1 \text { month, } \\
\text { Operated } \\
\text { as colon ca. }\end{array}$ & $\begin{array}{l}\text { WBC } 15 \\
.28 \text { No } \\
\text { eosinophilia- } \\
\text { Hypochromic } \\
\text { microcytic } \\
\text { anemia- } \\
\text { Thrombo } \\
\text { cytosis- } \\
\text { Albumin 1.8- } \\
\text { ESR 95. }\end{array}$ & Neg. & $\begin{array}{l}\text { Fungating mass } \\
\text { and bleeding } \\
\text { ulcers in the } \\
\text { cecum, friable } \\
\text { mass in } \\
\text { descending colon, } \\
\text { fungating } \\
\text { mass in } \\
\text { sigmoid. }\end{array}$ & $\begin{array}{l}\text { Three masses } \\
\text { at cecum, } \\
\text { splenic flexure } \\
\text { and sigmoid } \\
\text { colon+ mesenteric } \\
\text { L.N. enlargement. }\end{array}$ & $\begin{array}{l}\text { Total } \\
\text { Colectomy. }\end{array}$ & $\begin{array}{l}\text { Died in postop. } \\
\text { period from } \\
\text { bowl } \\
\text { perforations } \\
\text { and septic } \\
\text { shock. }\end{array}$ \\
\hline 4 & $19 \mathrm{y}$. & Male. & $\begin{array}{l}\text { Abdominal } \\
\text { pain, } \\
\text { weight loss } \\
\text { and abdominal } \\
\text { masses/ } 3 \\
\text { months, } \\
\text { operated as } \\
\text { appendicitis. }\end{array}$ & $\begin{array}{l}\text { WBC } 226.6 \% \\
\text { eosinophilia- } \\
\text { Hypochromic } \\
\text { microcytic } \\
\text { anemia- } \\
\text { Albumin } \\
2.5 \text {-ESR } \\
80 .\end{array}$ & Neg. & $\begin{array}{l}\text { Severe edema, } \\
\text { erythema and } \\
\text { narrowing at } 30 \\
\text { cm from anal } \\
\text { verge. }\end{array}$ & $\begin{array}{l}\text { Diffuse small } \\
\text { and large } \\
\text { bowel wall } \\
\text { thickening } \\
\text { mottled together } \\
\text { with stranding } \\
\text { of mesenteric } \\
\text { fat planes } \\
\text { and Para } \\
\text { aortic mass. }\end{array}$ & $\begin{array}{l}\text { Partial small } \\
\text { bowel resection } \\
\text { anastomosis + } \\
\text { Hartmann's } \\
\text { procedure. }\end{array}$ & $\begin{array}{l}\text { Died from } \\
\text { severe } \\
\text { malnutrition } \\
\text { and ARDS }\end{array}$ \\
\hline
\end{tabular}

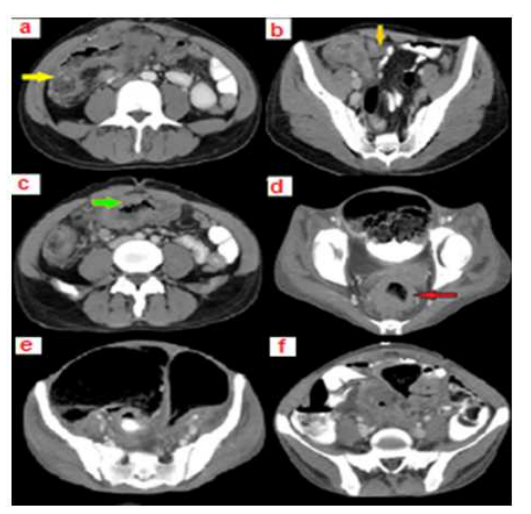

Fig. 1. (a) Thickening of the cecum yellow arrow, (b) Terminal ileum thickening with target sign orange arrow, (c) Transverse colon thickening green arrow, (d) Thickening of the rectum red arrow, (e) Hugely dilated bowel, (f) Fat stranding surrounding mesentery

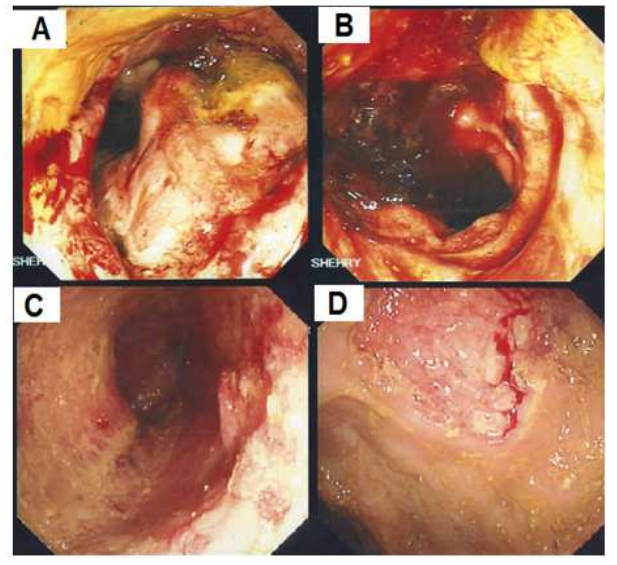

Fig. 2. Colonoscopic pictures showing; (A) Ulcerating mass obstructing the lumen, (B) Bleeding ulcers, (C) Polypoidal lesions, (D) Deep ulcer 


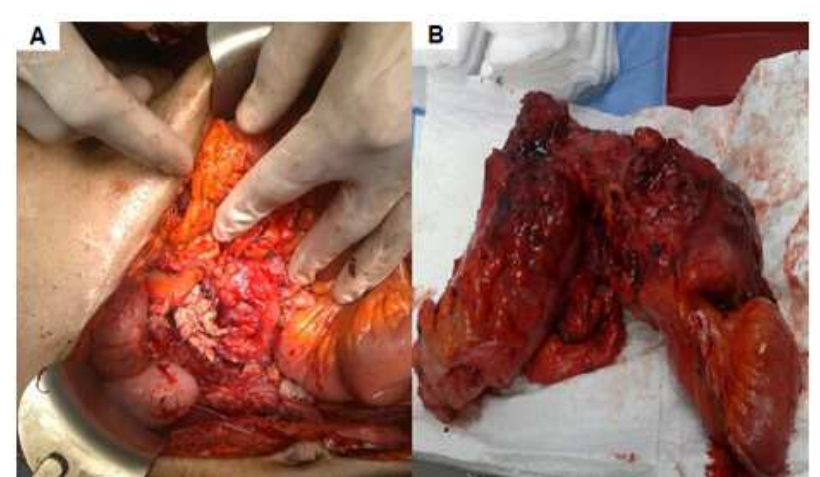

Fig. 3. (A) Intra operative pictures showing whitish deformed cecum, (B) Excised colon

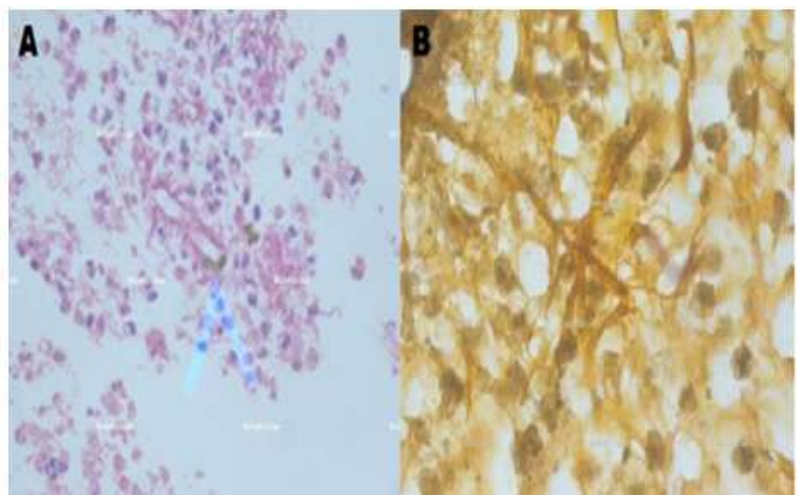

Fig. 4. (A) Broad hyphae surrrounded by an eosinophilic sheath arrow, (B) Gomori silver stain showing fungal hyphae in the tissue

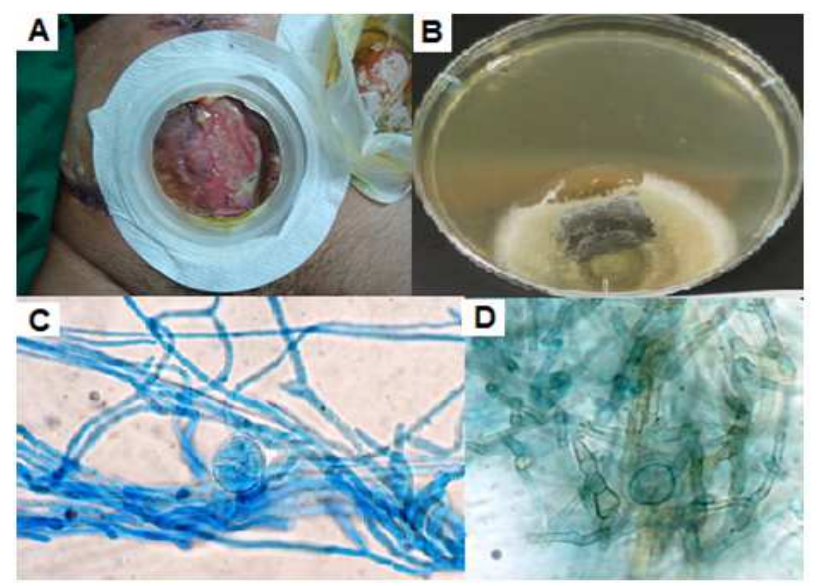

Fig. 5. (A) Enterocutanous fistula in patient case 4, (B-D) Sabouraud dextrose agar and Microscopic pictures showing broad hyaline hyphae with zygophores and zygospore formation characteristic of Basidiobolus sp
Colonoscopy showed inflammation, ulcerations and polypoidal lesions in sigmoid colon. Initial colonoscopic biopsies showed heavily infiltrated tissues by an acute and chronic inflammatory cells in the lamina propria with granulation tissue formation and vague collections of histocytes among which an occasional multinucleated giant cells were identified, there was crypt distortion, cryptitis and mucin depletion. After rolling out TB by culturing the tissue she was started on steroid with initial clinical improvement. Two weeks later, she presented again with deterioration of her symptoms and was started on TPN, at that time she had a generalized abdominal tenderness without guarding or rigidity and her lab work showed WBC $8.19 \times 10^{3} \mathrm{uL}^{-1}$ no eosinophilia, Hgb $9.3 \mathrm{~g}$ $\mathrm{dL}^{-1}, \mathrm{HCT} 28.9 \%$, MCV 68.3fL, MCH 22pg, Plt $1115 \times 10^{3} \mathrm{uL}^{-1}$, Creatinine $0.4 \mathrm{mg} \mathrm{dL}^{-1}$, K $3.1 \mathrm{mmol} \mathrm{L}^{-1}$, $\mathrm{Na} 137 \mathrm{mmol} \mathrm{L}^{-1}$, Total Protein $4.4 \mathrm{~g} \mathrm{dL}^{-1}$, Albumin 0.6 $\mathrm{g} \mathrm{dL}^{-1}$ and ESR $140 \mathrm{~mm} \mathrm{~h}^{-1}$. Colonoscopy showed worsening of the pervious lesions, deep ulcerations and more polypoidal lesions Fig. 2c and d. Colonoscopic biopsies for both histopathology and fungal culture showed presence of fungal hyphae, granulomatous inflammation and intense tissue eosinophilia with positive culture growth of $B$. ranarum Fig. 4. She was started on Itraconazole but she died as her condition was advanced and complicated by repeated hospital acquired infections and severe malnutrition.

\subsection{Case 3}

A previously healthy 72 years old Saudi male was referred to our hospital with history of abdominal mass and intermittent fever for one month, no history of abdominal pain, bleeding per rectum or weight loss, upon examination he was ill looking patient with BMI of 26.2 and normal vital signs. He had palpable hard tender mass in the left iliac fossa measuring $10 \times 15 \mathrm{~cm}$ in diameter. Laboratory workup showed WBC $15.28 \times 10^{3} \mathrm{uL}$ no eosinophilia, Hgb $10.6 \mathrm{~g} \mathrm{dL}^{-1}$, HCT $30 \%$, MCV 69.6fL, MCH 24.6pg, Plt $426 \times 10^{3} \mathrm{uL}$, ESR $95 \mathrm{~mm} \mathrm{~h}^{-1}$, Creatinine $0.9 \mathrm{mg} \mathrm{dL}^{-1}$, K $3.3 \mathrm{mmol} \mathrm{L}^{-1}$, Na $142 \mathrm{mmol} \mathrm{L}^{-1}$, Total Protein $5.9 \mathrm{~g} \mathrm{dL}^{-1}$, Albumin $1.8 \mathrm{~g}$ $\mathrm{dL}^{-1}$ and normal liver enzymes, CT abdomen with contrast showed three masses at the cecum, splenic flexure and the largest one in sigmoid colon with mesenteric lymph nodes enlargement. Colonoscopy showed fungating masses with bleeding ulcers at the cecum, descending and sigmoid colon. The histopathology for colonoscopic biopsies showed fragments of non-neoplastic tissues with granulation 
tissue formation and reactive inflammatory and hyperplastic changes. The patient underwent total colectomy, during surgery a huge three masses at cecum, sigmoid colon and splenic flexure were noted, the mass in splenic flexure was invading the surrounding structure with small perforation and thick pus discharge. After meticulous and difficult dissection a total colectomy performed with ilio-rectal primary anastomosis, the specimen sent for histopathology and cultures. The patient was diagnosed to have GI basidiobolomycosis based on identification of the fungus by culture Fig. 5b-d and the presence of fungal hyphea in the tissues with characteristic eosinophilic infiltration and he was started on Itraconazole. On day 25 post-operatively there was fecal discharge from lower part of the incision with guarding abdomen for that the Patient underwent explorative laparotomy which surprisingly showed five perforations at different sites; two perforations were managed by resection and primary anastomosis and the other three were repaired primarily in tow layer fashion. The patient condition complicated by ARDS and died on day 32 postoperative period from severe septic shock.

\subsection{Case 4}

A previously healthy 19 year old Saudi male was referred from peripheral hospital as case of abdominal masses for further workup and management. The patient was admitted there complaining of right iliac fossa pain for 3 months associated with fever, at that time he underwent emergency appendectomy for suspected appendicitis, during surgery irregular yellowish right pelvic mass with adherent omentum and loops of small intestine was noted along with minute perforation with small amount of thick pus collection, explorative laparotomy was done and intraoperatively an inflamed appendix was removed and the mass was biopsied. The histopathology showed many eosinophilic and multinucleated giant cells infiltration of the specimen associated with fat necrosis and granulomatous inflammation. On examination in our hospital he was ill looking patient and had BMI of 12.6 with normal vital signs, two clean abdominal incisions, no palpable masses or any evidence of peritonitis. The laboratory investigations showed WBC $22 \times 10^{3} \mathrm{uL}^{-1} \quad 6.6 \%$ eosinophilia, $\mathrm{Hgb} 10.1 \mathrm{~g} \mathrm{dL}^{-1}$, HCT $30.5 \%$, MCV 65.8fL, MCH $21.9 \mathrm{pg}$, Plt $385 \times 10^{3} \mathrm{uL}^{-1}$, Creatinine 0.5 $\mathrm{mg} \mathrm{dL}^{-1}, \mathrm{~K} 3.1 \mathrm{mmol} \mathrm{L}^{-1}$, Na $136.7 \mathrm{mmol} \mathrm{L}^{-1}$, ESR 80 $\mathrm{mm} \mathrm{h}^{-1}$, Total Protein $6.3 \mathrm{~g} \mathrm{dL}^{-1}$, Albumen $2.5 \mathrm{~g} \mathrm{dL}^{-1}$ and normal liver enzymes. CT of the abdomen with contrast showed diffuse wall thickening of small and large bowel loops which were mottled together with smudged fat planes, minimal fluid collection and large para-aortic heterogeneous mass measuring $3 \times 7 \mathrm{~cm}$. Colonoscopy sowed severe edema from rectum till the descending colon with severe narrowing at $30 \mathrm{~cm}$ from anal verge at which the gastroenterologist could not introduce the scope farther. Biopsies from that mass were taken under CT guidance which were consistent with fungal mass with typical granulomatous inflammation and eosinophilic infiltration with presence of fungal hyphae throughout the tissue. The culture for the biopsied tissue grew $B$. ranarum. Subsequently, the patient was started on Itraconazol. After 15 days postoperatively there was fecal matter discharge from the lower end of the mid line incision, repeated CT of the abdomen showed enterocutaneous connection Fig. 5A. The patient underwent laparotomy, during surgery multiple enteroenteric, enterocolic and enterocutaneous fistula were noted and extensive adhesions between bowel loops with big perforation in rectosigmoid area, resection and anastomosis of small bowel and closure of perforation site by Hartmann's procedure (surgical resection of the rectosigmoid colon with closure of the rectal stump and formation of an end colostomy) was done. Postoperatively the patient was admitted to ICU and started on TPN but died due to repeated in hospital infections and ARDS.

\section{DISCUSSION}

Gastrointestinal basidiobolomycosis is a rare infection caused by the fungus Basidiobolusranarum, of the order Entomophthorales, it was first isolated in 1955 from decaying plants in the United States and subsequently has been found in soil and vegetations throughout the world. Although the histological features of $B$. ranarum are well described in the skin and subcutaneous tissue (Kwon-Chung and Bennett, 1992), gastrointestinal involvement has presented considerable diagnostic difficulties and confusion because of nonspecific presenting signs and symptoms along with that there is no identifiable risk factors (Sugar, 2004) and observantly the causative agent lies deep beneath the mucosa. So, colonoscopic biopsies may be nonrepresentative.

It may masquerade as other clinical entities (Khan et al., 1998) delaying definitive diagnosis and treatment with more morbidity and mortality. However, it should be suspected in the differential diagnosis of any GI mass with subacute onset of symptoms including abdominal pain, fever and loss of weight with or without eosinophilia. 
GIB may be emerging as a result of various environmental and demographic factors, all of our cases were from the same region (southern part of Saudi Arabia) which characterized by warm and humid climate (Jarie et al., 2003), which is a good environment for fungal growth and common presence of some species of reptiles specially wall lizards which found to be one species of reptiles that have $B$. ranarum in their GI tract and assumed to be the cause in one of the reported cases, the ingestion of soil or animal excreta or food contaminated by either are the most believable route of infection in such cases. The current experience of treating patients is limited; however, it seems that early diagnosis is crucial along with surgical resection of the infected tissue and prolonged treatment with Itraconazole offering the best chance for curing this disease.

\section{CONCLUSION}

Diagnosis of GIB requires high index of suspicion, increased awareness of this rare disease help reach an early diagnosis and prompt starting treatment. The clinical features of which resemble those of inflammatory or neoplastic bowel disease. Whenever these diagnoses are entertained, basidiobolomycosis might be considered in the differential diagnosis.

\section{ACKNOWLEDGMENT}

The researchers would like to thank Dr. Sabah N. Nemri, histopathology department, Aseer central hospital and Dr. Mohamed E. Hamid, clinical microbiology and parasitology department, King Khalid University for reviewing the histopathology slides and cultures results and for their valuable help.

\section{REFERENCES}

Cameroon, H.M., 1990. Entomophthoromycosis. In: Tropical Mycoses, Mahgoub, E.S. (Ed.), Janssen Research Council, Beerse, Belgium, pp: 186-198.

El-Shabrawi, M.H., N.M. Kamal, R. Jouini, A. Al-Harbi and K. Voigt et al., 2011. Gastrointestinal basidiobolomycosis: An emerging fungal infection causing bowel perforation in a child. J. Med. Microbiol., 60: 1395-1402. DOI: 10.1099/jmm.0.028613-0

Greer, D.L. and L. Friedman, 1966. Studies on the genus Basidiobolus with reclassification of the species pathogenic for man. Sabouraudia, 4: 231-241. DOI: $10.1080 / 00362176685190521$

Gugnani, H.C., 1983. The pattern of deep mycoses in Nigeria. West Afr. J. Med., 2: 67-71.
Hussein, M.R., A.O. Musalam, M.H. Assiry, R.A. Eid and A.M. El Motawa et al., 2007. Histological and ultrastructural features of gastrointestinal basidiobolomycosis. Mycol. Res., 111: 926-930. DOI: 10.1016/j.mycres.2007.06.009

Jarie, A.A., I. Al-Mohsen, S.A. Jumaah, M.A. Hazmi and F.A. Zamil et al., 2003. Pediatric gastrointestinal basidiobolomycosis. Pediatr. Infect. Dis. J., 22: 1007-1014. DOI: 10.1097/01.inf.0000095166.94823.11

Joe, L.K., A. Pohan, N.I.T. Eng, A. Pohan and H.V.D. Meulen et al., 1956. Basidiobolus ranarum as a cause of subcutaneous mycosis in Indonesia. AMA Arch. Dermatol., 74: 378-383. DOI: 10.1001/archderm.1956.01550100046008

Khan, Z.U., B. Prakash, M.M. Kapoor, J.P. Madda and R. Chandy, 1998. Basidiobolomycosis of the rectum masquerading as Crohn's disease: Case report and review. Clin. Infect. Dis., 26: 521-523. PMID: 9502495

Khan, Z.U., M. Khoursheed, R. Makar, S. Al-Waheeb and I. Al-Bader et al., 2001. Basidiobolus ranarum as an etiologic agent of gastrointestinal zygomycosis. J. Clin. Microbiol., 39: 2360-2363. DOI: 10.1128/JCM.39.6.2360-2363.2001

Kwon-Chung, K.J. and J. E. Bennett, 1992. Medical Mycology. 1st Edn., Lea and Febiger, Philadelphia, ISBN-10: 0812114639, pp: 449-463.

Sugar, A.M., 2004. Agents of Mucormycosis and Related Species. In: Principles and Practice of Infectious Diseases, Mandell, G.L., J.E. Bennett and R. Douglas (Eds.), Elsevier Science Health Science Division, ISBN-10: 0443066728, pp: 1962-1972.

Sugar, A.M., 2010. Agents of Mucormycosis and Related Species. In: Mandell, Douglas and Bennett's Principles and Practice of Infectious Diseases, Mandell, G.L., J.E. Bennett and R. Dolin (Eds.), Churchill Livingstone, Philadelphia, PA., ISBN-10: 0443068399, pp: 2311-2321.

Sujatha, S., C. Sheeladevi, A.B. Khyriem, S.C. Parija and D.M. Thappa, 2003. Subcutaneous zygomycosis caused by Basidiobolus ranarum-a case report. Indian J. Med. Microbiol., 21: 205-206. PMID: 17643022

Sutherland-Campbell, H., 1929. An attempt to prove the etiologic factor in an epidemic among orange workers. Arch. Derm. Syphilol., 19: 233-254. DOI: 10.1001/archderm.1929.02380200061004

Thaxter, R., 1888. The Entomophthoreae of the United States. 1st Edn., Boston Society of Natural History, Boston, pp: 201.

Zahari, P., R.G. Hirst, W.A. Shipton and R.S.F. Campbell, 1990. The origin and pathogenicity of Basidiobolus species in Northern Australia. J. Med. Vet. Mycol., 28: 461-468. DOI: $10.1080 / 02681219080000581$ 